\title{
Literature, Human Rights and the Cold War
}

\author{
Andrew Hammond (University of Brighton)
}

The development of global justice was hampered by the Cold War. The Universal Declaration of Human Rights (UDHR) was adopted by the United Nations General Assembly on 10 December 1948 and aimed to establish political structures that would prevent the kind of atrocities that had been recently committed by Nazi Germany. As stated in the Preamble, the nations of the world would now focus their combined resources on 'the promotion of universal respect for and observance of human rights and fundamental freedoms' ${ }^{1}$ In theory, this was a historic shift in the adjudication of rights from national institutions to meta-institutional ideals of justice, dignity and the common good as guaranteed by the individual's membership of universal humanity. In practice, the UDHR was largely ineffective. Despite its increasing centrality to political thinking, the document was non-binding, lacking executive or judicial frameworks for enforcement and leaving the implementation of rights contingent upon unregulated state actors. As a consequence, the signatories of the UDHR failed to safeguard populations against tyrannical government, which paid scant regard to human rights or even human life. In a study of state oppression worldwide, R.J. Rummel estimates that 70 million political murders were committed between 1945 and the late 1980s, a figure that covers the highly publicised massacres in the Soviet Union and China and the lesser-known fatalities across the Global South (in Cambodia, Pakistan, Indonesia, Uganda, El Salvador and elsewhere). ${ }^{2}$ When factoring in the casualties of the one hundred or so 'hot' wars fought in the period, the death toll was far higher than the 60 million killed during the Second World War. As this chapter details, one response was a significant strand in literature which, appearing in

\footnotetext{
${ }^{1}$ United Nations, 'Universal Declaration of Human Rights', United Nations, http://www.un.org/en/universaldeclaration-human-rights/index.html (accessed 9 September 2017).

${ }^{2}$ Rummel, Death by Government, new edn (1994; New Brunswick and London: Transaction Publishers, 1997), p. 4.
} 
a wide variety of genres and regions, documented the unfulfilled promise of human rights discourse amidst the sustained violence of the Cold War.

\section{International Fault Lines}

The demands of the geopolitical conflict overshadowed the UDHR from the start. The period in which the Declaration was adopted saw the institutionalisation of Cold War division through the creation of Cominform (1947), the Truman Doctrine (1947), the Marshall Plan (1947), the Prague Coup (1948), the Berlin Blockade (1948-9), the Brussels Pact (1948) and the North Atlantic Treaty Organization (1949). Contrary to the UDHR's vision of global consensus, history was moving towards a hardening of the bloc system and a growth of superpower antagonism. Locked in a battle for global supremacy, neither the United States nor the Soviet Union wanted domestic or foreign policy checked by international law, a view shared by the United Kingdom, which in the late 1940s was still determined to retain control of its imperial possessions. Significantly, it was the post-war 'Big Three' that proved most resistant to the inclusion of enforcement mechanisms in the UDHR and that obstructed its implementation by the Human Rights Commission. For the next twenty years, Anthony Woodiwiss details, 'the sole body then charged with the task of interrogating states concerning their human rights records [...] refused to investigate any complaints [and] agreed only to receive very general descriptions of alleged violations for research purposes' ${ }^{3}$

Progress was also obstructed by disagreement over the sort of rights that should take precedence. For the Soviet Union, the emphasis needed to be on social and economic rights and the creation of adequate standards of life through state intervention in the realms of employment, health care and education. While a measure of 'welfarism' informed many western social democracies, the classic liberal creed was to curb the influence of the state and to place national wellbeing in the hands of the market, a creed that emphasised civil and political liberties over economic justice. With the UDHR taking the same line, Moscow abstained from the vote in the General Assembly in 1948 and pursued a course of censorship, internment and foreign invasion, earning international opprobrium as a result. It was not long before the reputation of the US was also tarnished. Alongside its refusal to ratify a number of human rights initiatives after 1948, Washington authorised anti-communist witch-hunts and civil rights violations at home and conducted extensive military actions abroad, all aiming at a worldwide containment of communism which, despite Carter's short-lived attempt at an ethical

\footnotetext{
${ }^{3}$ Woodiwiss, Human Rights (London and New York: Routledge, 2005), p. 89.
} 
foreign policy, continued in Reagan's hard-line stance against the 'evil empire' in the 1980s. ${ }^{4}$ At times, it seemed that the UDHR's only relevance to the superpowers was as a propaganda tool for concealing one's own human rights abuses by highlighting those of the other. As Mary Ann Glendon recounts, US-Soviet hostility soon meant that ' $[a]$ wedge was driven through the heart of the Declaration, severing its firm link between freedom and solidarity' ${ }^{5}$

The discourse of universal human rights not only exacerbated the conflict between 'First World' and 'Second World' - to use the language of the times - but also increased the isolation of the 'Third World'. The Cold War was in part a superpower struggle for influence in the emergent states in the Global South, whose political alignment had profound strategic significance for the East-West conflict. Yet the aim of countries across Africa, Asia and Latin America was not so much a role in the conflict than the achievement of political, social, economic and cultural rights lost during centuries of imperial coercion and exploitation. None of these would be won without a fight. In 1948, the predominance of imperial powers on the General Assembly meant that the UDHR, like the Enlightenment humanism which informed it, was grounded in the ideological assumptions of Western Europe and North America, paying scant regard to the needs of non-western regions. Most obviously, the national movements for independence in the 1950s were blocked by violent counter-insurgencies on the part of the imperial powers. During the 1960s and 1970s, similarly, the urgent need for collective development was barely accommodated by a western bloc that struggled to see beyond its 'preference for the free market economy and for a specific type of liberal democracy' ${ }^{6}$

The suspicion that human rights were in fact synonymous with western interests increased when the UDHR was extended by the Covenant on Civil and Political Rights and the Covenant on Social, Economic, and Cultural Rights, creating a tripartite accord known as the 'International Bill of Rights’ (1966). The Bill privileged the former covenant, by including complaints procedures, and downgraded the latter, by failing to include even monitoring mechanisms. This not only created a further split between the western and eastern blocs, but also angered many in the Global South, suggesting as it did that economic rights were aspirational rather than integral to stability and quality of life. Indeed, as the US-led system of global capitalism gained sway over most of the world, triumphing over the rival ambitions of Soviet communism, inequality systematically increased. The Non-Aligned Movement,

\footnotetext{
${ }^{4}$ Ronald Reagan quoted in Bradley Lightbody, The Cold War (London and New York: Routledge, 1999), p. 107.

${ }^{5}$ Glendon, A World Made New: Eleanor Roosevelt and the Universal Declaration of Human Rights (New York: Random House, 2001), p. 214.

${ }^{6}$ Koen De Feyter, Human Rights: Social Justice in the Age of the Market (London and New York: Zed Books, 2005), p. 19.
} 
emerging from the Bandung Conference of 1955, was a response to the dominance of the superpowers, aiming to advance the causes of self-determination and development, yet failed to check either the interference of Washington and Moscow or the destructiveness of local elites. For a large swathe of the world, the fact that the human rights covenants, conventions and charters ratified after the 1940s were still reliant on national governments to enforce them was a cruel paradox when '[g]overnments were the enemy against whom human rights were conceived as a defence'?

\section{Literature and Human Rights}

It was inevitable that writers and writing would play a major role in the burgeoning rights activism of the period. As critics have pointed out, the early arguments for inalienable rights, propounded by the Enlightenment philosophes and the French and American revolutionaries, were assisted by the dramatization of interiority, individual autonomy and inter-personal relations in the early novel, which worked to cultivate empathy across social boundaries and to advance new concepts of public duty. While the imagined communities of the fiction remained the nations of Western Europe and North America, the remit would expand after 1948, when the apparent universality of the UDHR helped to install the idea of rights in the global imaginary. Increasingly, authors used their work to expose the brutalising effects of imperialism, industrialisation and totalitarianism and to advocate for those who, still marginalised by class, gender, sexuality, race and ethnicity, found themselves 'excluded from the UDHR's conception of a common humanity'. ${ }^{8}$

Literary advocacy also extended to the defence of writing itself. Articles 19 and 27 of the UDHR, proclaiming the freedom 'to seek, receive and impart information and ideas through any media' and 'to participate in the cultural life of the community', were under attack in all blocs. ${ }^{9}$ Amongst the numerous political prisoners, dissidents and 'disappeared' in the period were novelists, dramatists, directors, poets and literary critics, many of whom were active in social movements for reform. Even a short list those persecuted - Agostinho Neto (Angolan), Aleksander Wat (Polish), Muriel Rukeyser (American), Andrei Sinyavsky (Russian), Dennis Brutus (South African), Augusto Boal (Brazilian), Nâzım Hikmet (Turkish), Yannis Ritsos (Greek), Faiz Ahmad Faiz (Pakistani) - indicates the global nature of the threat. As Homi

\footnotetext{
${ }^{7}$ Costas Douzinas, Human Rights and Empire: The Political Philosophy of Cosmopolitanism (Abingdon and New York: Routledge-Cavendish, 2007), p. 24.

${ }^{8}$ Woodiwiss, Human Rights, p. xiii.

${ }^{9}$ United Nations, 'Universal Declaration of Human Rights’.
} 
Bhabha has argued, literary freedom is vital for its own sake and for the sake of the many other freedoms that it represents. 'Narrative is not simply a social virtue', he once wrote, 'it is a moving sign of civic life. Those societies that turn their back on the right to narrate are societies of deafening silence: authoritarian societies, police states, xenophobic countries, nations traumatized by war or economic hardship' ${ }^{10}$ The oppositionalism that Bhabha locates in formal literature is equally present in witness testimony. During the Cold War, non-governmental organisations such as Amnesty International and Human Rights Watch, as well as local campaigners for women's rights, racial equality and political reform, sought oral and written records of human suffering for inclusion in field reports, mass letter-writing campaigns, judicial investigations and truth and reconciliation hearings. The narratorial quality of these counter-histories supports Joseph Slaughter’s idea that '[p]ersonal stories are the contemporary currency of human rights projects' and James Dawes's contention that 'human rights work is, at its heart, a matter of storytelling' ${ }^{11}$

In light of this, it is unsurprising that the critical study of literature and human rights has tended to focus on the life narratives of those with personal experience of state terror and public trauma. Positioned as both a product of and a stimulus to human rights reform, witness literature speaks of wider political shortcomings in a national community and aims to encourage readers' sympathy for the plight of the victims. The global spread of the genre is illustrated by Ruth First's attack on South African apartheid in 117 Days (1965), Rigoberta Menchú's account of atrocities against the Guatemalan Maya in Me Llamo Rigoberta Menchú (I, Rigoberta Menchú, 1983), Sally Morgan’s lament of the treatment of Indigenous Australians in My Place (1987) and Jung Chang's criticism of the Chinese Cultural Revolution in Wild Swans (1991). The first of these, a memoir of political imprisonment, typifies a strand of life narrative so common in the period that it became a distinct genre. The prison narrative exposed the brutality of governments throughout the world, including parts of the 'free world'; in the United States, for example, accounts of civil rights violations written by Malcolm X, Angela Davis and Ruben Johnson Carter evoked the nation as a kind of 'penitentiary with a flag' ${ }^{12}$ Just as testimonial writing had its own sub-genres so it overlapped with other categories of literature. These included such semi-autobiographical novels of personal and collective

\footnotetext{
${ }^{10}$ Bhabha, 'On Writing Rights', in Matthew J. Gibney, ed., Globalizing Rights: The Oxford Amnesty Lectures 1999 (Oxford: Oxford University Press, 2003), pp. 180-1.

${ }^{11}$ Slaughter, 'Foreword: Rights on Paper', in Elizabeth Swanson Goldberg and Alexandra Schultheis Moore, eds, Theoretical Perspectives on Human Rights and Literature (New York and London: Routledge, 2012), p. xiii; Dawes, 'Human Rights in Literary Studies', Human Rights Quarterly, Vol. 31, No. 2 (2009), p. 394.

${ }^{12}$ Carter quoted in Kay Shaffer and Sidonie Smith, Human Rights and Narrated Lives: The Ethics of Recognition (New York and Basingstoke: Palgrave Macmillan, 2004), p. 163.
} 
suffering as Mudrooroo’s Wild Cat Falling (1965), Alexander Solzhenitsyn’s Odin den' Ivana Denisovicha (One Day in the Life of Ivan Denisovich, 1962) and Bao Ninh’s Thân Phân Cua Tinh Yêu (The Sorrow of War, 1991). Similarly, the poetry of witness produced by Pablo Neruda, Wisława Szymborska, Claribel Alegría, Natalya Gorbanevskaya and Jack Mapanje, amongst many others, often returned to the 'storms of extermination' and 'the drifting twisted shadows of the dead' that were devastating their nations. ${ }^{13}$ The importance of (semi)autobiographical responses to suffering had become clear by the latter stage of the Cold War. Noting the outpouring of memoirs in the 1970s and 1980s, Joseph Slaughter is adamant that life writing had not only become a major vehicle for human rights claims but had also 'helped to create and consolidate many of the literary tastes and methods - as well as the memoir culture - that remain with us today, ${ }^{14}$

The extent of literary engagement with human rights, however, can only be understood by acknowledging its presence in writing more generally. As Kerry Bystrom points out, ‘[n]onfictional narratives of witness, while highly visible in human rights work, are only one of many different types or genres of literature [...] through which specific human rights claims are made'. ${ }^{15}$ During the Cold War, a wide range of fictional, dramatic and poetic genres proclaimed a belief in shared humanity and sought to transform the national and global community. Alongside the more obvious forms of testimonio and prison memoir were the multiple interventions of radical drama, community theatre, war poetry, magical realism and diasporic literature, all of which addressed the ideals and abuses of human rights as forcefully as autobiographical writing. One example is the type of novel that goes by the loose designation of 'political fiction'. An engaged, impassioned, polemical literature, driven by indignation at social injustice, political fiction was disparaged in mainstream western scholarship for prioritising political commentary over aesthetic quality and for frequently sinking into enraged essayism. Critics were especially disparaging of socialist realism, formulated at the Soviet Writers' Congress of 1934 and insistent that writers pursue 'the education of workers in the

\footnotetext{
${ }^{13}$ Aleksander Wat, 'Before Breughel the Elder', in Czesław Miłosz, ed., Postwar Polish Poetry, new edn (1965; Berkeley: University of California Press, 1983), p. 18, line 7; Bei Dao, 'The Answer', in Carolyn Forché, ed., Against Forgetting: Twentieth-Century Poetry of Witness (New York and London: W.W. Norton, 1993), p. 754, line 4.

${ }^{14}$ Slaughter, 'Foreword', p. xiv.

${ }^{15}$ Bystrom, 'Literature and Human Rights', in Thomas Cushman, ed., Handbook of Human Rights (London and New York: Routledge, 2012), p. 641. See also Sophia A. McClennen and Alexandra Schultheis Moore, 'Forms', in McClennen and Moore, eds, The Routledge Companion to Literature and Human Rights (London and New York: Routledge, 2016), p. 103; and Claire Seiler, 'Fictions of the Human in Postwar Japan', in Allan Hepburn, ed., Around 1945: Literature, Citizenship, Rights (Montreal and Kingston: McGill-Queen’s University Press, 2016), p. 175.
} 
spirit of socialism'. ${ }^{16}$ Although the resulting work was often formulaic, powerful examples of socialist realism appeared in the Soviet Union and later across the eastern bloc, the non-aligned world and the 'free world', including Ngũgĩ wa Thiongo'o's A Grain of Wheat (1967), Christa Wolf's Nachdenken über Christa T. (The Quest for Christa T, 1968) and William McIlvanney's Docherty (1975). These denounced social and economic injustices without any reduction in artistic merit, participating in the development of 'human rights fiction' as effectively as less clearly aligned political novels (such as Gabriel García Márquez’s El Otoño del Patriarca (The Autumn of the Patriarch, 1975), E.L. Doctorow's The Book of Daniel (1972) and Cristina Garcia’s Dreaming in Cuban (1992)). ${ }^{17}$

The power of political fiction to expose the abuses of the age is demonstrated by Ágota Kristóf's Le grand cahier (The Notebook, 1986), the first in a trilogy of novels about the psychological impact of European totalitarianism. Opening in the midst of World War Two, the text follows the fortunes of two young twin brothers who are evacuated from their town in an unnamed central European country (likely to be Kristóf's Hungary) and housed with their grandmother in a remote border village. After German occupation, the village transforms into “"an abominable world”' in which the basic tenets of humanity are exchanged for cruelty and selfishness. ${ }^{18}$ The twins not only learn the necessary tactics of survival, from begging to blackmail and murder, but also train themselves to withstand physical and emotional suffering, ensuring that '[i]t's someone else who gets hurt, someone else who gets burned, who gets cut, who feels pain'. ${ }^{19}$ The absence of human rights, in short, teaches them to abrogate the rights of others. The extent of their dehumanisation is apparent when the German occupiers are defeated and a Stalinist puppet regime is installed. For all the official proclamations of justice and liberty, the abuses of totalitarianism remain:

It is strictly forbidden to criticize or make jokes about our Liberators or our new government. On the strength of a mere denunciation, anyone can be thrown into prison without trial, without sentence. Men and women disappear without anyone knowing why,

\footnotetext{
${ }^{16}$ Quoted in Régine Robin, Socialist Realism: An Impossible Aesthetic, trans. by Catherine Porter (1987; Stanford: Stanford University Press, 1992), p. 11.

17 James Dawes, That the World May Know: Bearing Witness to Atrocity (Cambridge and London: Harvard University Press, 2007), p. 6.

${ }^{18}$ Kristóf, The Notebook, in Kristóf, The Notebook, The Proof, The Third Lie, trans. by Alan Sheridan, David Watson and Marc Romano (1986, 1988, 1991; New York: Grove Press, 1997), p. 138.

${ }^{19}$ Ibid., p. 17.
} 
and their families will never hear from them again. [...] Our country is surrounded by barbed wire; we are completely cut off from the rest of the world. ${ }^{20}$

Several years after the Soviet take-over, the boys' father turns up in the village and seeks their advice on crossing the border. Agreeing to help, they escort the father to the frontier and direct him into a minefield where, as they expected, he sets off a mine and creates a safe passage across, allowing one to escape to the West. The twin's heartless response to their father's death ('Yes, there is a way to get across the frontier: it's to make someone else go first') exemplifies the unemotional quality of the narration which, delivered by the twins in the first-person plural, communicates their suppressed trauma and internalisation of state violence. ${ }^{21}$ The failure of the UDHR to affect the eastern bloc is confirmed by the later works in the trilogy, La preuve (The Proof, 1988) and Le troisième mensonge (The Third Lie, 1991). Here, the full horror of authoritarian rule becomes clear during the 'imprisonments, disappearances, executions' which follow the Hungarian Uprising of 1956, an event that drove Kristóf into exile in Switzerland. ${ }^{22}$ In the second instalment, it emerges that the identical twins could well be one and the same person, a single selfhood that has invented a brother for companionship and solace during the decades of oppression. Yet as one of them admits, nothing offsets that fact 'that life is totally useless, that it's nonsense, an aberration, infinite suffering, the invention of a non-God whose evil surpasses understanding' ${ }^{23}$

\section{Human Rights in the Global South}

The hardships that East Europeans endured 'in the age of victorious justice', as Czesław Miłosz termed it, were repeated in parts of the non-aligned world. ${ }^{24}$ The principles of national and racial equality were established by the Declaration on the Granting of Independence to Colonial Countries and Peoples (1960) and advanced by the Convention on the Elimination of all Forms of Racial Discrimination (1965) and Declaration on the Right to Development (1986). For Wole Soyinka, even the original UDHR promised hope to those denied access to wealth and power, allowing 'every sentient member of society [to] weigh its claims against the excuses of dictatorships, intolerance [and] discrimination'. ${ }^{25}$ Nevertheless, the Global South had to

\footnotetext{
${ }^{20}$ Ibid., p. 159.

${ }^{21}$ Ibid., p. 183.

${ }^{22}$ Kristóf, The Proof, in Kristóf, The Notebook, The Proof, The Third Lie, p. 288.

${ }^{23}$ Kristóf, The Third Lie, in Kristóf, The Notebook, The Proof, The Third Lie, p. 471.

${ }^{24}$ Miłosz, 'Child of Europe', in Miłosz, The Collected Poems 1931-1987 (London: Penguin, 1988), p. 86, line 37.

${ }^{25}$ Soyinka, 'Foreword' to Universal Declaration of Human Rights: English, French, Hausa, Igbo and Yoruba (Ibadan: Institut français de recherche en Afrique, 1993), p. vi.
} 
contend with continuing colonialism in the first half of the Cold War, as well as the emergence of more indirect forms of foreign rule. Despite achieving an equal right to development, many countries across Africa, Asia and Latin America fell under the control of authoritarian local elites, whose subservience to western governments and corporations soon ensured a worse standard of life than at the time of independence. 'By 1989', Anne McClintock writes, 'the World Bank had \$225 billion in commitments to poorer countries, on condition that they [...] export their way to "progress", cut government spending on education and social services (with the axe falling most cruelly on women), devalue their currencies, remove trade barriers and raze their forests to pay their debt' ${ }^{26}$

The multiple injustices were recorded in postcolonial literature, a second genre that took the failures of the international human rights regime as a central theme. Texts such as Joseph Zobel's La Rue Cases-Nègres (Black Shack Alley, 1950), Chinua Achebe's A Man of the People (1966), Athol Fugard's The Island (1973), Epeli Hau'ofa's Tales of the Tikongs (1983), Jamaica Kincaid’s A Small Place (1988) and Ariel Dorfman's Death and the Maiden (1991) chronicled the historical and contemporary deficiencies of native and foreign governance. As the list shows, the common critical claim that the postcolonial Bildungsroman is 'a sort of novelistic wing of human rights', one that envisages 'contemporary subjects [...] incorporated into a global imaginary of universal rights', is applicable to a range of postcolonial genres. ${ }^{27}$ To extend the point, it was not uncommon for poetry to record how 'Corpses are scattered through a paradise' and how 'civilisation kicked us in the face' ${ }^{28}$ Oodgeroo Noonuccal's poetic advocacy for indigenous peoples was particularly blunt: 'Give us welcome, not aversion, / Give us choice, not cold coercion, / Status, not discrimination, / Human rights, not segregation' ${ }^{29}$

One of the major injustices documented in postcolonial literature was the plight of refugees and minority ethnicities who were being denied the citizenship on which normative standards of justice were based. The particular vulnerability of the stateless was ignored in the

\footnotetext{
${ }^{26}$ McClintock, 'The Angel of Progress: Pitfalls of the Term "Postcolonialism”', in Francis Barker, Peter Hulme and Margaret Iversen, eds, Colonial Discourse/Postcolonial Theory (Manchester and New York: Manchester University Press, 1994), p. 263.

27 Joseph R. Slaughter, Human Rights, Inc.: The World Novel, Narrative Form, and International Law (New York: Fordham University Press, 2007), p. 25; Sidonie Smith, 'Cultures of Rescue and the Global Transit in Human Rights Narratives', in Cushman, ed., Handbook of Human Rights, p. 627.

${ }^{28}$ Derek Walcott, 'A Far Cry from Africa', in Walcott, Collected Poems 1948-1984, new edn (1986; London: Faber and Faber, 1992), p. 17, line 4; David Diop, 'The Vultures', in Gerald Moore and Ulli Beier, eds, The Penguin Book of Modern African Poetry, new edn (1963; London: Penguin, 1998), p. 328, line 2.

${ }^{29}$ Noonuccal, 'Aboriginal Charter of Rights', in Noonuccal [Kath Walker], The Dawn Is at Hand: Selected Poems, new edn (1991; London and New York: Marion Boyars, 1992), pp. 60-1, lines 23-6.
} 
UDHR and barely lessened after the Convention Relating to the Status of Refugees (1954) and the Protocol Relating to the Status of Refugees (1967), which still viewed rights as the preserve of recognised citizens. As Hannah Arendt argued, the conditions of life for marginalised and displaced communities had failed to improve after 1945, despite mass displacement in Europe being a major stimulus to the UDHR, leaving sections of humanity whose 'plight is not that they are not equal before the law, but that no law exists for them'. ${ }^{30}$ Again, the topic was addressed in postcolonial poetry, which often focused on what Roque Dalton termed 'the forever undocumented' and Jimmy Santiago Baca called 'immigrants in our own land'. ${ }^{31}$ Derek Walcott's 'Certain things here are quietly American' (1984) explores the theme in the context of St. Thomas, an island formerly governed by the British and Danish-Norwegian empires and later absorbed into the US Virgin Islands. Though the effects of US rule are 'quietly American', a less violent imposition than earlier forms of imperialism, they are no less absolute. ${ }^{32}$ The point is made through Walcott's commentary on the steady destruction of traditional island landscape which condemns the intrusion of modernity while accepting its inevitability ('we all know that the dust / is industrial and must be suffered'). ${ }^{33}$ The power of the American overseers extends to political and economic arrangements. For African-Caribbean migrants who arrive in search of work, the local economy functions as an exclusive, hierarchical entity, even raising physical barriers against those it considers unwonted foreigners. As Walcott writes, these are the

illegal immigrants from unlucky islands

who envy the smallest polyp its right to work.

Here the wetback crab and the mollusc are citizens,

And the leaves have green cards. ${ }^{34}$

The lament for the crises of migrant communities recurred in many other postcolonial texts Ghassan Kanafani’s Rijal fi-a-shams (Men in the Sun, 1962), Ama Ata Aidoo’s Our Sister Killjoy (1997), Tarek Eltayeb’s Mudun bila nakhil (Cities without Palms, 1992) - which denounced a global order that continued to privilege the bourgeois white male citizen while

\footnotetext{
${ }^{30}$ Arendt, The Origins of Totalitarianism, new edn (1951; New York: Harcourt, Brace, Jovanovich, 1968), p. 295.

${ }^{31}$ Dalton, 'Love Poem', in Forché, ed., Against Forgetting, p. 605, line 30; Baca, 'Immigrants in Our Own Land', in Baca, Immigrants in Our Own Land and Selected Early Poems (New York: New Directions, 1990), p. 12, title.

${ }^{32}$ Walcott, 'Certain things here are quietly American', in Walcott, Collected Poems, p. 486, line 1.

${ }^{33}$ Ibid., p. 486, lines 18-19.

${ }^{34}$ Ibid., p. 486, lines 14-17.
} 
ignoring the entitlements of others. Makau Mutua is not alone in concluding that the human rights regime is 'fundamentally Eurocentric', a new-fangled version of imperial discourse that aligns the 'human rights zealot' to 'the colonial administrator, the Bible-wielding Christian missionary, the merchant of free enterprise [and] the exporter of political democracy' ${ }^{35}$

\section{Nightmares of the Cold War}

The social criticism found in postcolonial texts was occasionally matched in intensity by that of dystopian literature, a cautionary form of writing that takes the most negative features of society to an imaginative extreme in order to highlight their threat to humanity. Although often considered a futuristic genre, Cold War dystopian fiction could be equally focused on the here and now, as indicated by Erika Gottlieb’s characterisation of Eastern European dystopianism as 'an accurate reflection of the "worst of all possible worlds" experienced as a historical reality' ${ }^{36}$ In part, the genre was a reaction against the utopianism which had dominated western speculative writing before the twentieth century, locating in its prescriptions for social perfection an urge towards standardisation and tyranny. In Fernando Rosenberg's view, any universal blueprint for human life, including normative codes of justice, 'could also be the mask of terror, an absolute principle of sovereign demand that [...] justifies cruel dehumanization'. ${ }^{37}$ With many writers alarmed at the utopian blueprints of both US capitalism and Soviet communism, the optimistic prognoses of previous eras soon passed to their dystopian opposite, established as a global current through such novels as René Barjavel's La nuit des temps (The Ice People, 1968), Janet Frame’s Intensive Care (1970), Nuruddin Farah’s Sweet and Sour Milk (1979), Li Ang’s Shafu (The Butcher's Wife, 1983), Margaret Atwood’s The Handmaid's Tale (1985) and Vladimir Voinovich’s Moskva 2042 (Moscow 2042, 1986). In their treatments of Cold War institutions, dystopian writers rarely strayed from the nightmarish portrait of totalitarianism offered in George Orwell's Nineteen Eighty-Four (1949): “"If you want a picture of the future”, the text proclaims, "“imagine a boot stamping on a human face - for ever", 38

\footnotetext{
${ }^{35}$ Mutua, Human Rights: A Political and Cultural Critique (Philadelphia: University of Pennsylvania Press, 2002), pp. 11, 20.

${ }^{36}$ Gottlieb, Dystopian Fiction East and West: Universe of Terror and Trial (Montreal and Kingston: McGillQueen's University Press, 2001), p. 17.

${ }^{37}$ Rosenberg, After Human Rights: Literature, Visual Arts, and Film in Latin America, 1990-2010 (Pittsburgh: University of Pittsburgh Press, 2016), p. 5.

${ }^{38}$ Orwell, Nineteen Eighty-Four, new edn (1949; Harmondsworth: Penguin, 1983), p. 230.
} 
The pessimism of Cold War culture was also seen in the theatre, where audiences were faced with unremittingly negative forecasts of the future. Samuel Beckett's Fin de partie (Endgame, 1957), Wole Soyinka’s A Dance of the Forests (1960), Václav Havel’s Vyrozuměni (The Memorandum, 1965) and Griselda Gambaro’s El Campo (The Camp, 1967) all charted the collapse of Enlightenment humanism and the institutional maltreatment of individual and community. In British drama, Howard Brenton's The Churchill Play (1974) was adamant that western populations were not protected from the worst injustices of the Cold War. Set in the same year as Orwell's dystopia, the play portrays a period of austerity and social unrest that brings to power a governing coalition of the far-right Conservative Party and a post-socialist Labour Party. Determined to reduce dissent, the coalition incarcerates left-wingers in a gulag of prison camps which are run on the basis that those who 'flout basic human rights . . . themselves forfeit human rights'. ${ }^{39}$ In the so-called Churchill Camp, working-class internees are subjected to deprivation and torture by a brutal military that is considering a take-over of the country. As a new prisoner realises, the camp promises an eradication of human dignity:

We are going lower than the lower depths. [...] God knows, there's no difficulty in degrading the human animal, it’s vulnerable enough. A few blows, a few weeks' starvation, a few nights without sleep. And man? Would slander a slug under a stone to call him animal. ${ }^{40}$

The dehumanisation of those seeking a fairer society is partly addressed through the motif of Winston Churchill, referenced in the name of the camp and in a play about the wartime leader that the internees write and perform to a visiting parliamentary sub-committee on prison welfare. As the guards make clear, the play needs to be an agreeable hagiography suitable for a figure who led a 'war against a monstrous tyranny'. ${ }^{41}$ For the prisoners, however, Churchill is not an icon of democratic resistance to Nazism, and therefore a forerunner to the signatories of the UDHR, but a member of an imperialistic elite who revealed his true colours when fighting in the Battle of Omdurman in 1898, deploying soldiers against Welsh miners in 1910 and dividing Europe at Yalta in 1945. With the prisoners ridiculing Churchill throughout the performance, the play-within-a-play becomes a subversive device by which an oppressed class can comment on authoritarian Britain: as one of the visiting dignitaries remarks drily, '[t]he

\footnotetext{
${ }^{39}$ Brenton, The Churchill Play, in Brenton, Plays: One (London and New York: Methuen, 1986), p. 156.

${ }^{40}$ Ibid., pp. 129-30.

${ }^{41}$ Ibid., p. 164.
} 
play's the thing in which to catch the conscience of an old bitch of a democracy'. ${ }^{42}$ Additionally, Brenton's self-reflexive exposure of the mechanics of theatrical performance, by presenting on stage rehearsals, scene changes and lighting rigs, acts as a form of Brechtian alienation, exposing the constructedness of bourgeois society in order to pinpoint its availability for change. Indeed, the performance culminates in an occupation of the camp by the prisoners, an insurgency which, although quelled, indicates the hopes of a playwright with a self-proclaimed 'Marxist view of the world'. ${ }^{43}$

Although Brenton's work is positioned in the traditions of left-wing drama, elements of The Churchill Play overlap with postmodernism, another major genre that focused attention on an embattled humanity. Emerging in the 1950s and 1960s, postmodernism was an experimental current in literature and the arts that charted the horrors of a contemporary world which, in atrocities such as the Holocaust and Hiroshima, was not only shattering conventional belief systems but also outperforming the human imagination. The current found fertile ground in the United States, where the artistic search for truth was hindered by the constructed worlds of governmental propaganda, media imagery and advertising, raising doubts about the possibilities of autonomous thought. Kurt Vonnegut's Slaughterhouse-Five (1969), Thomas Pynchon's The Crying of Lot 49 (1966) and Ursula Le Guin's The Left Hand of Darkness (1969) expressed 'an abiding American dread that someone else is patterning your life [and] that conditioning is ubiquitous'. ${ }^{44}$ While postmodern scepticism is commonly interpreted as an attack on humanist values, the authors revealed a deeply humanist concern with the challenges that late capitalism presented to the 'dignity and worth of the human person', as the Preamble of the UDHR expressed it. ${ }^{45}$ For example, Lawrence Ferlinghetti’s ‘In Goya’s Greatest Scenes' (1958) finds little difference between the tortured figures of the Spanish artist's late work and the 'strung-out citizens / in painted cars' crowding contemporary America, finding distinction only in the latter's exposure to 'bland billboards / illustrating imbecile illusions of happiness' ${ }^{46}$ In contrast to the self-aggrandising claims of 'free world' propaganda, the society encountered in postmodernist poetry was typically evoked as ‘wreckage, dreck and waste’ (Adrienne Rich)

\footnotetext{
${ }^{42}$ Ibid., p. 170.

${ }^{43}$ Quoted in Tony Mitchell, File on Brenton (London and New York: Methuen, 1987), p. 90.

${ }^{44}$ Tony Tanner, City of Words: American Fiction 1950-1970 (London: Jonathan Cape, 1971), p. 15.

${ }^{45}$ United Nations, 'Universal Declaration of Human Rights'.

${ }^{46}$ Ferlinghetti, 'In Goya's Greatest Scenes', in Ferlinghetti, A Coney Island of the Mind (New York: New Directions, 1958), p. 10, lines 33-4, p. 9, lines 30-1.
} 
and as a 'Congress of sorrows' (Allen Ginsberg). ${ }^{47}$ The tribulations described in the literature were hardly on the scale of the poverty and oppression experienced in the Global South; as Patricia Waugh details, however, it did something to capture the helplessness, vacuity and dread of western capitalist societies which felt themselves to be 'heading for a new Dark Age, a new barbarism'. 48

The ambivalent position of human rights during the Cold War - as a concept proclaimed but largely unpractised by the global order - has persisted into the present. In a period of accelerated globalisation, the degradation of national populations has not only recurred in state activity, as evidenced by the US-led 'war on terror', but also increased amongst non-state actors, with multinational companies and economic organisations showing more interest in capitalising on the geopolitical age than in upholding universal moral absolutes. As critics point out, we have entered an age when human rights violations 'are often committed in the Orwellian name of human rights themselves, cloaked in the palliative rhetoric of humanitarian intervention, the chivalric defense of women and children, the liberalization of free markets [and] the capitalist promise of equal consumerist opportunity'. ${ }^{49}$ At the turn of the twenty-first century, the scale of paralysis was indicated by the UN Development Programme's Human Development Report 2000, which was still emphasising the need for governmental accountability, multiparty democracy and the eradication of poverty. ${ }^{50}$ For writers concerned about the contemporary crisis, there is no greater source of inspiration than their twentiethcentury precursors. Although frequently banned or censored, the human rights literature of the Cold War insisted on documenting the horrors of state violence and the difficulties of political resistance, as well as on sustaining the hope that a universal community grounded in inalienable rights would one day be achieved. In Claribel Alegría’s words, this was the widespread dream that the 'sinister / and well-planned disorder' of the age would finally yield to 'a more kindly world'.51

\footnotetext{
${ }^{47}$ Rich, 'An Atlas of the Difficult World', in Rich, An Atlas of the Difficult World: Poems 1988-1991 (New York and London: W.W. Norton, 1991), p. 4, line 49; Ginsberg, 'Howl', in Ginsberg, Collected Poems 1947-1980, new edn (1985; London and Harmondsworth: Penguin, 1987), p. 131, line 82.

${ }^{48}$ Waugh, Practising Postmodernism/Reading Modernism (London and New York: Edward Arnold, 1993), p. 7.

${ }^{49}$ Slaughter, Human Rights, p. 2.

${ }^{50}$ See De Feyter, Human Rights, pp. 20-1.

${ }^{51}$ Alegría, 'From the Bridge’, in Forché, ed., Against Forgetting, p. 592, lines 103-4, 110.
} 


\section{BIBLIOGRAPHY}

Achebe, Chinua, A Man of the People (London: Heinemann, 1966).

Aidoo, Ama Ata, Our Sister Killjoy or Reflections from a Black-Eyed Squint, new edn (1977; Harlow: Longman, 1988).

Alegría, Claribel, 'From the Bridge’, in Carolyn Forché, ed., Against Forgetting: TwentiethCentury Poetry of Witness (New York and London: W.W. Norton, 1993), 589-92.

Ang, Li, The Butcher's Wife, trans. by Howard Goldblatt and Ellen Young (1983; London: Peter Owen, 1989).

Arendt, Hannah, The Origins of Totalitarianism, new edn (1951; New York: Harcourt, Brace, Jovanovich, 1968).

Atwood, Margaret, The Handmaid's Tale, new edn (1985; London: Virago, 1987).

Baca, Jimmy Santiago, 'Immigrants in Our Own Land', in Baca, Immigrants in Our Own Land and Selected Early Poems (New York: New Directions, 1990), 12-13.

Barjavel, René, The Ice People, trans. by Charles Lam Markmann (1968; London: Mayflower, 1972).

Bao Ninh, The Sorrow of War: A Novel, trans. by Frank Palmos and Phan Thanh Hao (1991; London: Vintage, 1998).

Barker, Francis, Peter Hulme and Margaret Iversen, eds, Colonial Discourse/Postcolonial Theory (Manchester and New York: Manchester University Press, 1994).

Beckett, Samuel, Endgame, trans. by Samuel Beckett (1957; London and Boston: Faber and Faber, 1964).

Bei Dao, 'The Answer', in Carolyn Forché, ed., Against Forgetting: Twentieth-Century Poetry of Witness (New York and London: W.W. Norton, 1993), 754-5.

Bhabha, Homi K., 'On Writing Rights', in Matthew J. Gibney, ed., Globalizing Rights: The Oxford Amnesty Lectures 1999 (Oxford: Oxford University Press, 2003), 162-83.

Brenton, Howard, Plays: One (London and New York: Methuen, 1986).

Chang, Jung, Wild Swans: Three Daughters of China (1991; London: Harper, 2012).

Cushman, Thomas, ed., Handbook of Human Rights (London and New York: Routledge, 2012).

Dalton, Roque, 'Love Poem’, in Carolyn Forché, ed., Against Forgetting: Twentieth-Century Poetry of Witness (New York and London: W.W. Norton, 1993), 605.

Davis, Angela, Angela Davis: An Autobiography, new edn (1974; London: Women’s Press, 1990). 
Dawes, James, That the World May Know: Bearing Witness to Atrocity (Cambridge and London: Harvard University Press, 2007).

, 'Human Rights in Literary Studies', Human Rights Quarterly, Vol. 31, No. 2 (2009), 394-409.

De Feyter, Koen, Human Rights: Social Justice in the Age of the Market (London and New York: Zed Books, 2005).

Diop, David, 'The Vultures', in Gerald Moore and Ulli Beier, eds, The Penguin Book of Modern African Poetry, new edn (1963; London: Penguin, 1998), 328-9.

Doctorow, E.L., The Book of Daniel, new edn (1972; London: Picador, 1982).

Dorfman, Ariel, Death and the Maiden: A Play in Three Acts, trans. by Ariel Dorfman (1991; London: Nick Hern, 2011).

Douzinas, Costas, Human Rights and Empire: The Political Philosophy of Cosmopolitanism (Abingdon and New York: Routledge-Cavendish, 2007).

Eltayeb, Tarek, Cities without Palms, trans. by Kareem James Palmer-Zeid (1992; London: Arabia Books, 2009).

Farah, Nuruddin, Sweet and Sour Milk (London: Allison \& Busby, 1979).

Ferlinghetti, Lawrence, ‘In Goya’s Greatest Scenes’, in Ferlinghetti, A Coney Island of the Mind (New York: New Directions, 1958), 9-10.

First, Ruth, 117 Days: An Account of Confinement and Interrogation under the South African 90-Day Detention Law, new edn (1965; Johannesburg: Penguin, 2006).

Frame, Janet, Intensive Care (New York: George Braziller, 1970).

Fugard, Athol, John Kani and Winston Ntshona, The Island, new edn (1973; Paris: Théâtre des Bouffes du nord, 1999).

Gambaro, Griselda, The Camp, in Diana Taylor and Sarah J. Townsend, eds, Stages of Conflict: A Critical Anthology of Latin American Theater and Performance (Ann Arbor: University of Michigan Press, 2008), 225-44.

Garcia, Cristina, Dreaming in Cuban, new edn (1992; New York: Ballantine Books, 1993).

García Márquez, Gabriel, The Autumn of the Patriarch, trans. by Gregory Rabassa (1975; London: Picador, 1978).

Ginsberg, Allen, 'Howl', in Ginsberg, Collected Poems 1947-1980, new edn (1985; London and Harmondsworth: Penguin, 1987), 126-33.

Glendon, Mary Ann, A World Made New: Eleanor Roosevelt and the Universal Declaration of Human Rights (New York: Random House, 2001). 
Goldberg, Elizabeth Swanson, and Alexandra Schultheis Moore, eds, Theoretical Perspectives on Human Rights and Literature (New York and London: Routledge, 2012).

Gottlieb, Erika, Dystopian Fiction East and West: Universe of Terror and Trial (Montreal and Kingston: McGill-Queen’s University Press, 2001).

Hau’ofa, Epeli, Tales of the Tikongs (Auckland: Longman Paul, 1983).

Havel, Václav, The Memorandum, trans. by Vera Blackwell (1965; London: Eyre Methuen, 1981).

Hepburn, Allan, ed., Around 1945: Literature, Citizenship, Rights (Montreal and Kingston: McGill-Queen’s University Press, 2016).

Kanafani, Ghassan, Men in the Sun \& Other Palestinian Stories, trans. by Hilary Kilpatrick (1962; Boulder and London: Lynne Rienner Publishers, 1999).

Kincaid, Jamaica, A Small Place, new edn (1988; London: Virago, 1988).

Kristóf, Ágota, The Notebook, The Proof, The Third Lie, trans. by Alan Sheridan, David Watson and Marc Romano (1986, 1988, 1991; New York: Grove Press, 1997).

Le Guin, Ursula K., The Left Hand of Darkness, new edn (1969; New York: Penguin, 2016).

Lightbody, Bradley, The Cold War (London and New York: Routledge, 1999).

Malcolm X, The Autobiography of Malcolm X, new edn (1965; London: Hutchinson \& Co., 1966).

Mandle, Jon, Global Justice (Cambridge: Polity Press, 2006).

McIlvanney, William, Docherty, new edn (1975; London: Sceptre, 1987).

Menchú, Rigoberta, I, Rigoberta Menchú, ed. by Elisabeth Burgos-Debray (1983; London and New York: Verso, 1984).

Miłosz, Czesław, 'Child of Europe', in Miłosz, The Collected Poems 1931-1987 (London: Penguin, 1988), 85-9.

Mitchell, Tony, File on Brenton (London and New York: Methuen, 1987).

Morgan, Sally, My Place (Fremantle: Fremantle Arts Centre Press, 1987).

Mudrooroo [Colin Johnson], Wild Cat Falling (London: Angus \& Robinson, 1965).

Mutua, Makau, Human Rights: A Political and Cultural Critique (Philadelphia: University of Pennsylvania Press, 2002).

Ngũgĩ wa Thiongo'o, A Grain of Wheat, new edn (1967; London: Penguin, 2002).

Noonuccal, Oodgeroo, 'Aboriginal Charter of Rights', in Noonuccal [Kath Walker], The Dawn Is at Hand: Selected Poems, new edn (1991; London and New York: Marion Boyars, 1992), 60-1. 
Orwell, George, Nineteen Eighty-Four, new edn (1949; Harmondsworth: Penguin, 1983).

Pynchon, Thomas, The Crying of Lot 49, new edn (1966; London: Vintage, 1996).

Rich, Adrienne, An Atlas of the Difficult World: Poems 1988-1991 (New York and London: W.W. Norton, 1991).

Robin, Régine, Socialist Realism: An Impossible Aesthetic, trans. by Catherine Porter (1987; Stanford: Stanford University Press, 1992).

Rosenberg, Fernando J. After Human Rights: Literature, Visual Arts, and Film in Latin America, 1990-2010 (Pittsburgh: University of Pittsburgh Press, 2016).

Rummel, R.J., Death by Government, new edn (1994; New Brunswick and London: Transaction Publishers, 1997).

Slaughter, Joseph R., Human Rights, Inc.: The World Novel, Narrative Form, and International Law (New York: Fordham University Press, 2007).

Solzhenitsyn, Alexander, One Day in the Life of Ivan Denisovich, trans. by Max Hayward and Ronald Hingley (1962; New York: Praeger Publishers, 1963).

Soyinka, Wole, A Dance of the Forests (London: Oxford University Press, 1963). , 'Foreword' to Universal Declaration of Human Rights: English, French, Hausa, Igbo and Yoruba (Ibadan: Institut français de recherche en Afrique, 1993), v-vi.

Tanner, Tony, City of Words: American Fiction 1950-1970 (London: Jonathan Cape, 1971). Voinovich, Vladimir, Moscow 2042, trans. by Richard Lourie (1986; San Diego: Harcourt Brace Jovanovich, 1987).

Vonnegut, Kurt, Slaughterhouse-Five, new edn (1969; London: Triad Grafton Books, 1979). Walcott, Derek, Collected Poems 1948-1984, new edn (1986; London: Faber and Faber, 1992).

Wat, Aleksander, 'Before Breughel the Elder', in Czesław Miłosz, ed., Postwar Polish Poetry, new edn (1965; Berkeley: University of California Press, 1983), 18.

Waugh, Patricia, Practising Postmodernism/Reading Modernism (London and New York: Edward Arnold, 1993).

Wolf, Christa, The Quest for Christa T, trans. by Christopher Middleton (1968; London: Virago, 1982).

Woodiwiss, Anthony, Human Rights (London and New York: Routledge, 2005).

Zobel, Joseph, Black Shack Alley, trans. by Keith Q. Warner (1950; Boulder and London: Lynne Rienner Publisher, 1997). 